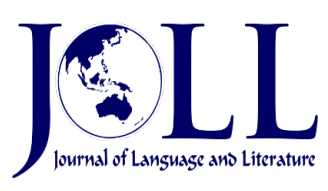

Vol. 21 No. 2, October 2021, pp. 242-251

DOI: 10.24071/joll.v21i2.3009

Available at https://e-journal.usd.ac.id/index.php/JOLL/index

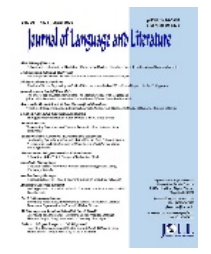

This work is licensed under a Creative Commons Attribution-ShareAlike 4.0 International License.

\title{
Persona in social media: A Case Study on Baim Paula Youtube Channel
}

\author{
Aidatul Chusna \\ aidatul.chusna@unsoed.ac.id \\ Faculty of Humanities, Universitas Jenderal Soedirman, INDONESIA
}

\begin{abstract}
Social media enables its users to participate in creating and sharing media contents through their accounts; thus, it gives opportunity to gain popularity for anyone, including celebrity. This paper is aimed at revealing celebrities' strategy to increase and maintain their popularity by constructing self-image through social media. Videos from Baim Paula youtube channel are selected as the main data of the analysis, considering Baim Wong's success as celebrity and content creator. Using textual approach, the vidoes created and shared are analized as a cultural text which demonstrates celebrities' self-representation in social media. The result shows that Baim Wong performs various self-images through his videos contents. His prank videos indirectly indicate authenticity and honesty entitled to Baim Wong's image, as a strategy to create closeness to his fans. He also construcs an altruistic persona by giving presents and/or money to his pranked targets. Another self-representation is seen in videos about his daily activities with family and friends. Through these videos, Baim Wong constructs his image as a family man. The persona performed in social media has successfully attracted more fans/ subscribers and enhanced his fame. Subsequently, it generates profit not only from his YouTube channel, but also from advertising agencies and TV stations that hire him.
\end{abstract}

Article information

Keywords: Baim Wong; celebrities; authentic; family; persona

\section{Introduction}

The development of web 2.0 technology and social media allows anyone to become famous. With the convenience provided by the technology, vlogging has become a trend and has even spawned many new celebrities from cyberspace, namely Atta Halilintar, Ria Ricis,
Arif Muhammad, Suhay Salim, Rachel Goddard, Sara Gibson, Anya Geraldine, Awkarin, and many more. Starting with sharing information, images, or videos in their social media accounts, these so-called micro celebrities or influencer are now able to earn a lot of benefits from their posts. 
Youtube is the most popular platform for Indonesian social media users, aged between 16 to 64 years, with the percentage of accessing this media reaching $88 \%$ (Jayani, 2020). With the slogan "Broadcast Yourself", Youtube has become a medium for sharing creative works through video sharing and interacting through the comment section, even benefiting from uploaded videos. Profit is an inseparable aspect of using social media, including YouTube. Pelle Snickars and Patrick Vanderau (Snickars \& Vonderau, 2009, p. 11) revealed that the uniqueness of Youtube lies in how the platform negotiates and navigates between the community and commerce. Youtube is a media based on industry and its users. In line with Snickars and Vanderau, Burgess and Green (Kidd, 2016, p. 70) said that YouTube is a space for content creators, amateurs and professionals, and corporationsincluding advertising companies, forging good cooperation mutually beneficial; thus, making youtube the most important mediator in today's global media market.
Unlike other social media platforms, youtube is a space for its users to create creative content and share various kinds of videos, including music videos (song covers), short films, cooking videos, travel videos, or even videos of everyday activities.

The success of these micro-bloggers or vloggers is apparently followed by many celebrities in Indonesia who are trying their luck to become YouTubers. With the status of a celebrity who is certainly well-known and even has many fans, it becomes easier for these celebrities to get followers or subscribers. Baim Wong can be said to be one of the most successful celebrities who also become a YouTuber today, with an income of up to billions of rupiah per month and the number of subscribers to his YouTube channel named Baim Paula as much as more than 16.8 million, in just about four years (Baim Paula's YouTube Stats (Summary Profile) - Social Blade Stats, n.d.), as shown in Figure 1 below:

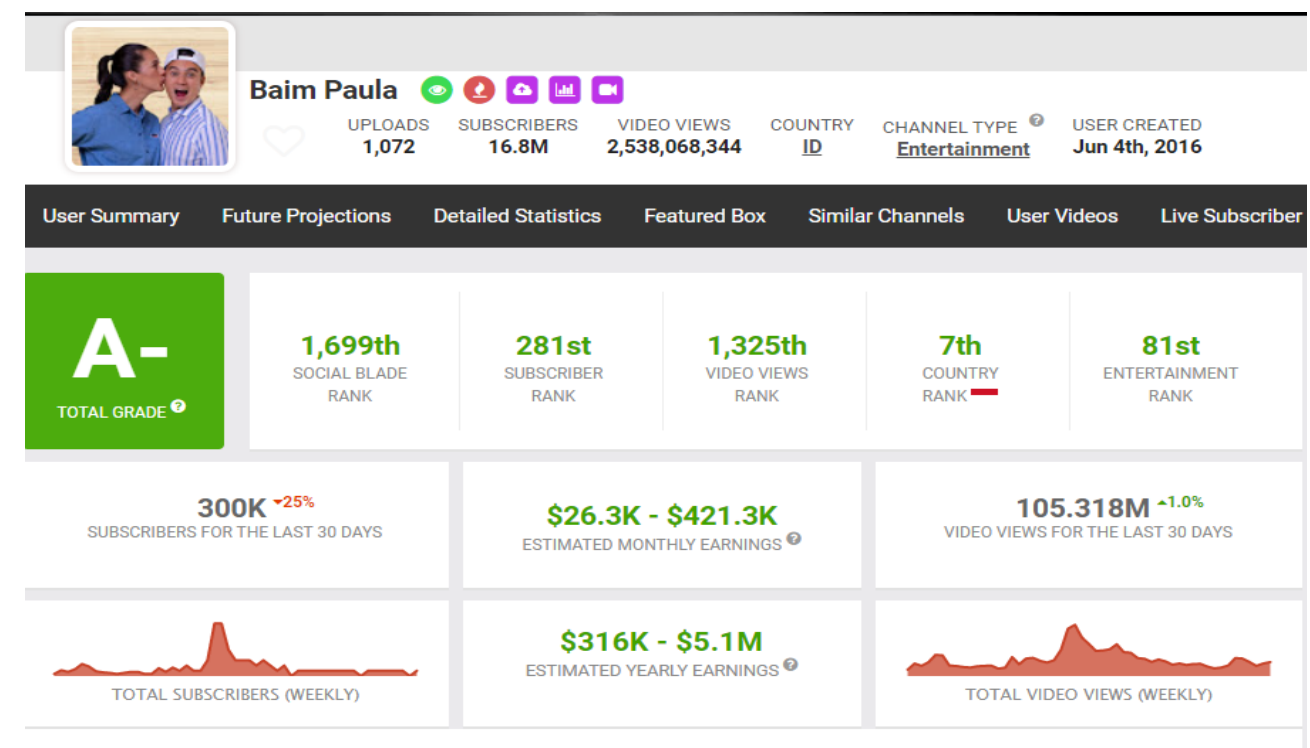

Figure 1. data statistics of Baim Paula Youtube Channel, taken from socialblade.com

Vlogging is becoming a new form of life narrative which is documented in video form and shared with the public. Through his YouTube channel, Baim Wong shares more videos about daily activities with his family, closest friends, and the community around him. Through his videos, Baim Wong also presents a different self-image from what fans and the public usually see in mass media or television.

Studies on micro celebrity or micro influencers related to fame gained through social network sites have been widely carried out, including studies on the practice of celebrating (celebrification) conducted through social networks (Maghfiroh \& 
Hapsari, 2015, p. 57), linguistic studies on the use of hashtags (\#) by micro-celebrities in twitter (Page, 2012). Meanwhile, research on the impact of endorsements carried out by micro-celebrities or influencer in Indonesia shows that emotional ties mediate authenticity by word of mouth and the possibility of purchasing products (Cahyaningtyas \& Sutikno, 2019). Another study is about the strategies carried out by micro-celebrities in the twitter room as well as interactions with their followers (Rahmawan, 2014, p. 1).

This study found several strategies adopted by micro-celebrities/ influencer to maintain relationships with their followers, namely stimulated conversation, audience recognition, and self-disclosure. Yet, there are only few studies on the phenomenon of celebrities turning to social networking sites. Meanwhile, there are more Indonesian celebrities who are starting to use social media (facebook, instagram, youtube, etc) to perform themselves, such as Rafi Ahmad, Baim Wong, Dedi Corbuzier, Luna Maya, and many others. One of the study on celebrity in social media is conducted by Yessica (Yessica, 2017), focusing on the role of Chelsea Olivia as a celebrity endorser via Instagram on consumer purchase interest. Using a survey techniquue, the result shows that Chelsy Olivia's constructed characters, namely expertise, trust, and attractiveness give significant effect on consumer buying interest. Another study, conducted by Sutriono and Haryatmoko (Sutriono \& Haryatmoko, 2018), examine celebrities capital mobilization in social media as a contested arena. By using Bourdeu's concept, the study shows that symbolic capital owned by celebrities becomes their power that are often converted to social and economic capital.

However, all of these previous studies do not highlight the use of social media by celebrities (and their production teams) to build their persona. Focusing on Baim Wong's youtube channel, this paper discusses how celebrities construct their self-representation through social networking sites, especially YouTube. Therefore, this discussion cannot be separated from the logic of social media as media that is interactive and participatory, as well as commercial. Thus, it is expected to be able to add a new insight into this phenomenon, especially related to self-image construction within the mechanism of social networking sites.

\section{Methodology}

This study uses a descriptive qualitative method as it aims at describing the phenomenon of celebrity's self-representation in social media. (Baim Paula) youtube channel is selected as a case study. As Stake (Cresswell, 1998, p. 62) said, case studies focus on either a certain case- because of its uniqueness, it requires study (intrinsic case study), or a case viewed as the instrument to describe an issue (instrumental case study). Despite the various data may be used in a case study, this paper only used documents and audio visual material (youtube videos) to analyze the issue of selfrepresentation in social media. Within the scope of cultural studies, the audio-visual material -as in the form of youtube videos, is among a wide array of cultural texts used as a unit of textual analysis approach to discuss a wider cultural issue or phenomenon (Davis, 2008, p. 57). This study argues that Baim Wong's success as a content creator indicates a cultural phenomenon related to the self representation in social media. Thus, to investigate further, collecting data becomes the initial step of the study.

Data collection is conducted by doing observation the videos uploaded and shared in Baim Paula youtube channel. Since the beginning of Baim Paula's YouTube channel, a number of 1211 videos have been uploaded and shared, covering various themes, namely: daily activities with family and friends (family vlog), pranks, Ramadan activities, charity and give away. From the various themes presented in this channel video, I chose the three themes that got the most views, namely such as prank, ping pong challenge, Ramadan, sahur with Bapau, QnA, giveaway, and Bapau vlog (source: youtube Baim Paula). The videos that raise these three themes becomes the main data that I analyze to see the strategy carried out by the production team of the Bapau youtube channel in constructing Baim Wong's selfrepresentation through social media mechanisms, especially YouTube. As the 
supporting data, I gathered information related to Baim Wong from online media.

The analysis utilizes textual approach by focusing on Baim Wong's persona through narration and the visual image presented in the videos. Concepts of celebrity and selfrepresentation in social media are the theoretical framework applied in the analysis. On the study of celebrity, Marwick and boyd (Jerslev \& Mortensen, 2018) argue that celebrities should be understood not merely as a figure, but more importantly, as a performative practice, which "involves ongoing maintenance of a fan basis, performed intimacy, authenticity and access, and construction of a consumable persona" (Jerslev \& Mortensen, 2018, p. 158). Thus, persona is important for celebrity. It has social function, namely a cultural formation that participates in the 'horizon of hope' in the daily life of young people and others. (Kanai, 2015, p. 232) Celebrities are considered to have this function, because they are often portrayed as ideal figures in various mass media. Therefore, celebrities do not only have an entertainment role, but also serve as role models and guides for the lives of their audiences (Pringle, 2004, p. xxii).

Concepts of self-construction by Goffman is another useful theoretical foundation of the analysis. According to Goffman (Kidd, 2016, p. 64 ), in a society that strictly regulates public and private boundaries, performance is social interaction in daily communication. Like a dramaturgy, identity is always displayed situationally and relationally at the basic social stages of life, including the formal and public identity- which is on stage and the more informal and private one, that is shown at the backstage, where stage behavior is trained. The backstage is thus an inaccessible area to the audience, as it is where the important secret of a show comes from and the players may act outside of the characters they are playing.

The boundaries of the private and public spheres as described by Goffman above change along with the development of media technology. Meyrowitz calls the middle region (middle area) a new social arena that merges the flow of information from the two previous areas and reveals some performances that were previously hidden from the audience. The uncertainty of the public and the private boundaries has made the behavior of the middle region, such as appearances on television and other media, to continue to be debated. Middle region also supports discussions about authenticity and privacy in social media.

Social media is a commercially based platform, so that the self-display space provided for its users cannot be separated from this goal. In the end, the self that is displayed undergoes changes following this mechanism. As described by Marwick (Kidd, 2016, p. 67), social media encourages its user audience to present themselves and profit through the visibility and attention it receives. To increase social status, a product or celebrity constructs a persona for marketing purposes. This persona has been heavily edited, controlled, and monitored, following the commercial purposes that represent selfrepresentation. The technical mechanisms of social media reflect the values in which they are produced, namely a culture dominated by commercial interests. This kind of changes is rooted in contemporary capitalism, particularly the philosophy of deregulation and privatization known as neoliberalism.

\section{Results and Discussion}

This section discusses the video content created and shared in Baim Wong's youtube channel, as a strategy to build his persona. The contents become narrative texts that shape a celebrity's self-representation and generates high visibility and popularity, making him more known than ever. This paper will look at three content themes that have received many viewers and describe the persona formed as a self-representation of Baim Wong's figure.

\section{Prank Video}

Baim Wong's popularity as a content creator can be seen in the prank videos that he shared in his YouTube channel. The video where he plays the role of a crazy person has even got more than 10 million views. Prank videos of being crazy have been carried out several times in several areas in Jakarta and 
outside Jakarta. In some of these videos he also invites his closest friends, among artists and other public figures, to play a prank as crazy person.

In one video- uploaded on January 22, 2019 , for example, Baim Wong pretended to be a lunatic roaming the streets and begging for mercy on the intended target, who is the public he meets directly on the street. This video has been watched more than 12 million times, and has even become the sixth trending topic on YouTube (Indita, 2019). Various reactions were shown when he approached multiple targets; some were afraid and immediately left, but some were sympathetic by giving food or money, as seen in figure 2 below:

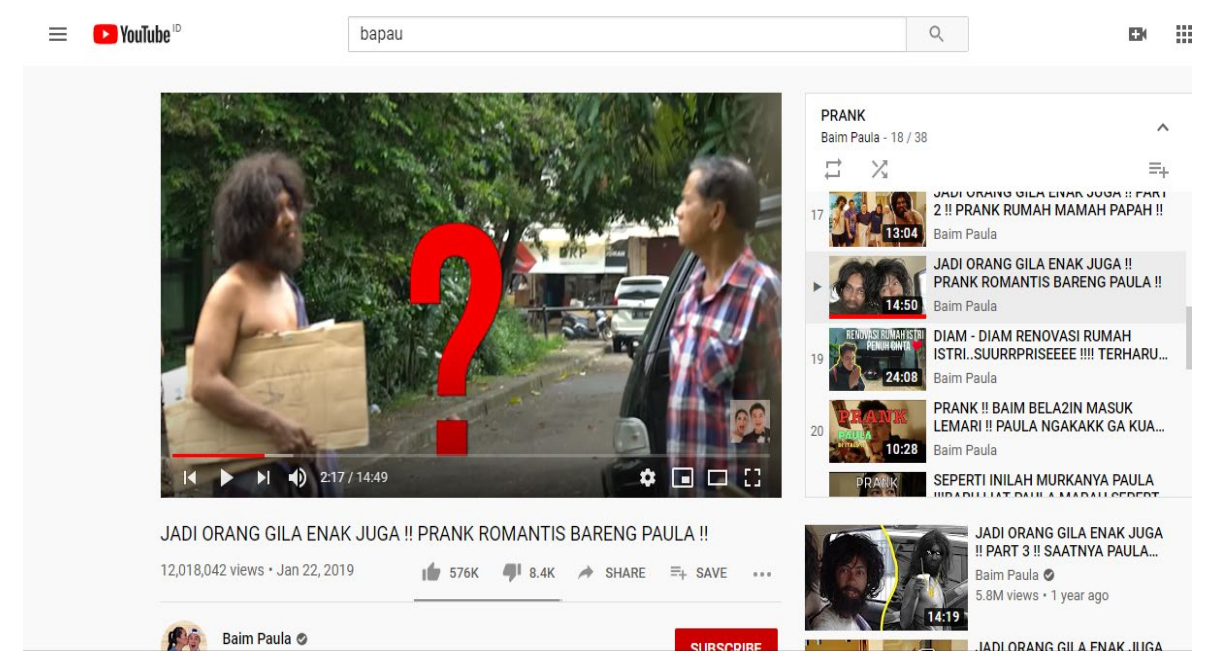

Figure 2. Baim Wong acted as a mentally-ill person in his prank video

Prank video is not relatively new. Initially, it is widely used by comedians as part of their comedy content. They use hidden cameras to trick their targets, who don't realize they are part of an action that ends in shock and unexpected. The important moment in this prank action is when the prankster shows himself and explains the real situation. Reaction videos like this have become a standard for various video formats uploaded on youtube, spearheaded by the Fine Brothers (Benny and Rafi), a comedian duo who even founded an online entertainment company whose popularity stems from the creation of special reaction video channels (Giles, 2018, p. 119).

Reaction videos are very popular and are liked by young people who also make up the majority of internet users. Reactions that produce emotions spontaneously are believed to have authenticity values that are not found in other entertainment genres. The spontaneity and authenticity shown in the prank videos shared by Baim Wong also indirectly builds his self - representation in the media. By showing that the videos do not use scripts (the dialogue is spontaneous) and prank targets from the public that he meets on the streets are randomly picked, it represents Baim Wong's character as a spontaneous, honest, and unengaged self. In addition, this video also shows the preparations before the prank is carried out, such as the atmosphere at his home when he is dressed up like a beggar and a crazy person. What is shared on YouTube video seems like what Meyrowitz calls a middle region which seems to merge the private and public aspects of a celebrity, as well as sharing some information that should be hidden 'backstage'. Thus, a question raised: Is the preparation part shown in the video trully a 'backstage'part? The backstage area, as Goffman defined (Kidd, 2016, p. 64), is locked away from the audience, as the important secret of a show is kept here and the players may act outside of the characters they are playing. When it has been 'unlocked', it 
becomes another stage. It is part of the stage to perform Baim Wong's self- identity.

As described above, the self represented in social media is a form of persona that has been polished, monitored and followed commercial ideas. As a celebrity, authenticity and honesty are very important values to enhance selfimage as a "brand" that is liked by users. Dyer (Franssen, 2019, p. 315) says that fame (stardom) is shaped by "a rhetoric of honesty or authenticity, two qualities that are highly valued by stars because they guarantee that they are telling the truth, and appearing as they are" (a rethoric of sincerity or authenticity, two qualities greatly prized in the stars because they guarantee, respectively, that the star really means what he or she says, and that the star really is what she or he appears to be). In the end, authentic and honest self-construction becomes self-image (personal branding) as a form of selfpromotion for commercial purposes.

\section{Altruism}

Altruism is defined as an "unselfish regard for or devotion to the welfare of others" (Altruism / Definition of Altruism by MerriamWebster, n.d.) It is a behaviour or quality attributed to people who centers on someone or something other than themselves. Many of the videos uploaded and shared on Baim Paula
(Bapau) youtube channel depict Baim Wong's altruistic behavior. The popularity of prank videos not only shows the entertainment aspect, but also the nature of generosity as part of the persona that is constructed by Baim Wong and his production team.

In every prank that is carried out, Baim Wong almost always chooses targeted people who are considered to come from lower economic class. At the end of each prank, he always gives a certain amount of money to the people who were targeted, so it was not uncommon for the prank video to end with a picture of the happiness of the targets who received the prize money from Baim Wong. The camera is aimed at the target's emotional and blissful facial expressions after receiving the money/ assistance.

Baim Wong's generosity even received appreciation from YouTube CEO Susan Wojcicki in her tweet on April 14, 2020, highlighting his 'Gemas' (Gerakan Memakai Masker/Movement to Wear Masks), a nationwide action project aimed at raising people's awareness to wear masks to prevent Covid-19 transmission and providing 30 million masks for underprivileged people. The tweet was then uploaded to Baim Wong's Instagram account- as seen in figure 3 , which increase and strengthen Baim Wong's altruistic persona in social media.

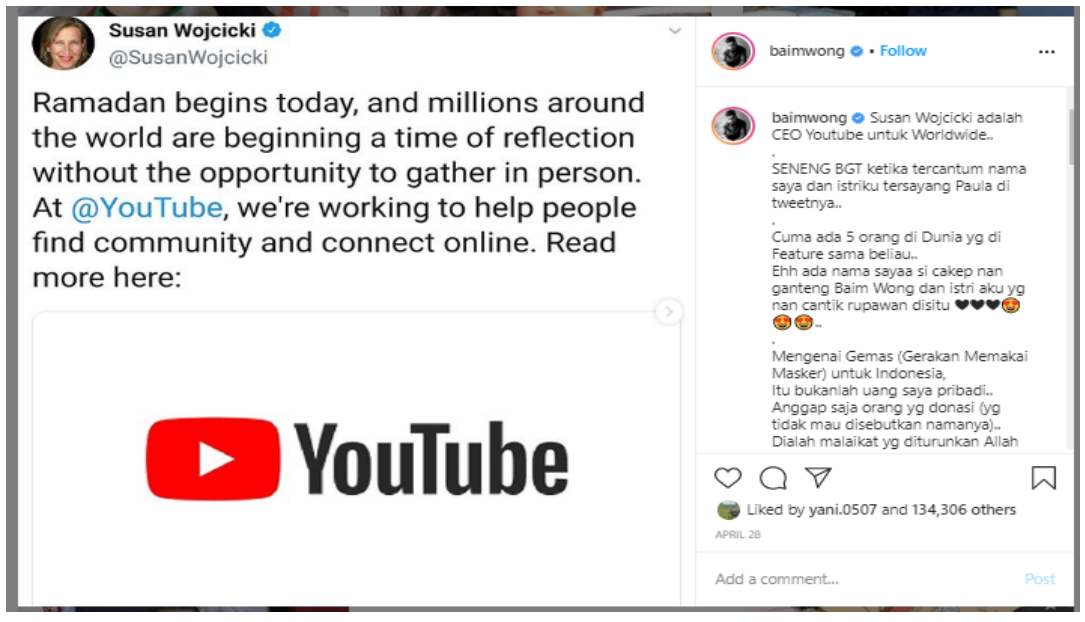

Figure 3. Appreciation of Youtube CEO for Baim Wong's generous action

Baim Wong's self-representation as a generous person strongly supports the image he has built as a celebrity. As previously described, celebrities have a social function as role models for society. The positive image that continues to be built through the posted and 
shared videos is surely increasing the number of fans or subscribers of the figure. In the fasting month of this year, Baim Paula's number of YouTube subscribers has increased sharply with an average number of views of 1 million for just one video, and has become the highest-earning YouTuber in Indonesia based on YouTube Adsense every month ranging from $\$ 64.7 \mathrm{~K}-\$ 1,000,000$ or Rp. 970,5000 .000 - Rp. 15,000,000,000 (Agustina, 2020). It also benefits Baim Wong with the increasing profit.

\section{Family Vlogging}

Family vlogging is among the popular video formats uploaded in Youtube. Time Magazine noted that the time spent watching family channel videos has increased by $90 \%$ in 2017 (Eaton, 2019). As vlogging become more popular and gives revenues, many families are making it as their main income. They create video content with the entire family members, while earning enough money for them. Working in a stress-free environment and aren't restricted in certain time or hours, family vlogging becomes the main reason for these vloggers (Suha, 2020). The Ace Family, La brant Fam, Eh Bee Family, and Daily Bumps are some the family channels who earns profits from their videos. In Indonesia, to name the few, the similar phenomenon refers to the popularity of family channels of Gen Halilitar, Rans Entertainment, and The Hermansyah A6.

Baim Wong's family vlogging has also become one of his popular videos. Baim Wong shares his daily activities with his family, closest friends, and also the Bapau youtube production team. Several videos tell about her household journey with Paula Verhoeven, from getting acquainted, having a relationship, then getting married, to becoming new parents. The video shared on December 28, 2019 about the process of the birth of his child, even received more than 8 million views (PROSES KELAHIRAN BABY KIANO TIGER WONG .. - YouTube, n.d.). In this video, the emotions of joy and compassion are shown through Baim Wong and the extended family accompanying the birth of his son. This 15minute video shows quite detailed pictures, from the moment of Baim Wong and Paula's son was taken out of the operating room and examined by doctors and nurses to the moment of Baim Wong initiated adzan (the Islamic prayer call) while holding him gently. This video exhibits Baim Wong's loving family that every one is dreaming to have. Moreover, the close-up shot on Baim Wong performing adzan to his son indicates another important character to be shown to the audience, namely the image of Baim Wong as a good Muslim. These two self-images, a family man and a good Muslim, are the manifestation of celebrity as an ideal figure, which serves as role model and guide for the lives of his audiences (Pringle, 2004, p. xxii).

Vlog presenting daily family activities shows the fluidity of the private and public sphere in social media. This vlog shows the closeness the celebrity wants to share with his fans, which is rarely seen in the image of celebrities in the mainstream media. Presenting private activities to the public is a strategy to get closer to fans and make them part of the artist's life or vice versa. In this family vlogging content, Baim Wong tends to choose to build a self-image as member of the community.

Video contents that are spontaneous, unfiltered and more intimate are seen in many of these celebrity family videos. This type of content format is often found in the videos of influencer families who are not from the artist's family, because it accentuates their status as ordinary people with daily activities that are not much different from the general audience. Abidin (Abidin, 2017, p. 4) mentions several themes used by influencer families in the video content they upload, including: (1) developmental milestones, which document the development of children in the family, such as using a potty for the first time or when they lose their first tooth; (2) Family celebrations, such as holiday celebrations and birthdays, which show how families commemorate special events in their personal moments; (3) errands, which illustrate how the family is managed, such as talking to a built-in camera during mealtimes or in the car while driving school, so that it looks more haphazard and spontaneous; (4) confession, which indicates that the family has private conversations or shares personal reflections, such as when parents reveal parenting mistakes or when 
children reflect on increased fame. (5) reactions, which contain children's responses to current events, such as viral videos and global tragedies, to spontaneous questions from parents to children, to pranks that are done to capture children's unexpected kindness in public; (6) Logistics, which broadcasts how the family manages the vlog and their involvement with followers, such as reading fan letters in front of the camera and conducting question and answer sessions (Q\&A).

Playing on social media, Baim Wong also adopts these everyday activity themes, to create a simple self-image and be part of the general public. He shares many videos related to his child's growth and development, such as the first time he tastes food, he has his first teeth, and his first walk. He also shared videos of celebrating Eid with his wife, child and family on his website channel. What are shown in such vlog is a type of experiences that most family have and deal with in their daily life. Performing the family activities represent Baim Wong's figure as a member of society. He positions himself equally in front of his followers despite his fame and fortune. In addition, the light and spontaneous everyday themes not only show closeness and openness to his fans and audiences in general, but also the authenticity of self-images formed through social media.

However, it is worth remembering that social media works within the logic of capitalism. The authenticity shown in the videos is part of the persona that has been adapted to commercial purposes, so that social media users also form multiple identities, by negotiating in the realm of private and public life. The intimacy displayed in Baim Wong's video content is part of the commodification of self-representation he does for commercial purposes. Baim Wong's persona, which was formed through family vlog content, has proven to generate profits not only from his YouTube channel, but also from advertisements and endorsements of baby products, as well as many programs on several private television stations, with a more or less the same format, namely family content.

\section{Conclusion}

The development of web 2.0 technology and social media encourages celebrities to take advantage of these media to increase and maintain their social status as celebrities. In contrast to mass media and electronic media such as magazine and television, mass media has a character that allows its users to become actors of production and consumption. Social networking sites as a medium of communication, connection and socialization are interactive and participatory. Baim Wong is one of the Indonesian celebrities who has successfully utilized social network sites to increase his popularity and gain profit as a content creator through the Baim Paula youtube channel. The uploaded and shared content depicts the personas of various identities through spontaneous, relaxed and 'truthful' performances. This kind of performance is widely liked because it brings the celebrity closer to his fans through authentic self-representation and seems banal, so that it shows the celebrity is part of ordinary society, like the general public. The spirit of generosity is another self-image that is very prominent in the video content he uploads. As a celebrity, good self-representation will make him not only an idol in the world of entertainment, but also a role model and guide for society. However, social media is commercial based media, so its content is intended to make a profit. Baim Wong's selfrepresentation is a persona that benefits him as a celebrity. The visibility and popularity of the shared video content has also increased his fame as a celebrity and has brought him very high income from the profession as a content creator, product endorsement, television program programs, and other partnerships with various companies. 


\section{References}

Abidin, C. (2017). \#familygoals: Family Influencers, Calibrated Amateurism, and Justifying Young Digital Labor. Social Media + Society, 3(2), https://doi.org/10.1177/205630511770 7191

Agustina, A. (2020). 5 YouTuber Berpenghasilan Tertinggi, Baim \& Raffi Bersaing Sengit, Atta Ketinggalan / merdeka.com.

https://www.merdeka.com/artis/5youtuber-berpenghasilan-tertinggibaim-raffi-bersaing-sengit-attaketinggalan.html

Altruism / Definition of Altruism by MerriamWebster. (n.d.). Retrieved December 7, 2020, from https://www.merriamwebster.com/dictionary/altruism

Baim Paula's YouTube Stats (Summary Profile) - Social Blade Stats. (n.d.). Retrieved December 5, 2020, from https://socialblade.com/youtube/c/bai mpaula

Cahyaningtyas, D., \& Sutikno, B. (2019). The Impact of Micro-Celebrity Endorsement in Indonesia.

http://etd.repository.ugm.ac.id/home/d etail_pencarian/173240

Cresswell, J. W. (1998). Qualitative Inquiry and Research Design. SAGE publication.

Davis, A. (2008). Investigating Cultural Producers. In M. Pickering (Ed.), Research Methods for Cultural Studies (pp. 53-67). Edinburgh University Press.

Eaton, K. (2019). Top 10 Family Channels on YouTube. https://neoreach.com/topfamily-channels-youtube/

Franssen, G. (2019). Sincerity and authenticity in celebrity culture: introduction. In Celebrity Studies (Vol. 10, Issue 3, pp. 315-319). Routledge.

https://doi.org/10.1080/19392397.2019 .1630117

Giles, D. . (2018). Twenty-First Century Celebrity: Fame in Digital Culture. Emerald Publishing Limited.

Indita. (2019, January 24). Video Prank Jadi Orang Gila Masuk Trending di Youtube, Baim Wong: Udah Kaya Youtuber Banget Halaman 2 - TribunStyle.com.

https://style.tribunnews.com/2019/01/ 24/video-prank-jadi-orang-gila-masuk- trending-di-youtube-baim-wong-udahkaya-youtuber-banget?page $=2$

Jayani, D. H. (2020). 10 Media Sosial yang Paling Sering Digunakan di Indonesia I Databoks.

https://databoks.katadata.co.id/datapub lish/2020/02/26/10-media-sosial-yangpaling-sering-digunakan-di-indonesia

Jerslev, A., \& Mortensen, M. (2018). Celebrity in the Social Media Age. In A. Elliot (Ed.), Routledge Handbook of Celebrity Studies (pp. 157-174). Routledge.

Kanai, A. (2015). Jennifer Lawrence, remixed: approaching celebrity through DIY digital culture. Celebrity Studies, 6(3), 322-340. https://doi.org/10.1080/19392397.201 5.1062644

Kidd, J. (2016). Representation. Routledge.

Maghfiroh, L., \& Hapsari, N. F. (2015). A Celebrification of Celebgram on Instagram: A Case Study of @Shireeen. Allusion, 4(1), 57-62.

Page, R. (2012). The linguistics of selfbranding and micro-celebrity in Twitter: The role of hashtags. Discourse and Communication, 6(2), 181-201. https://doi.org/10.1177/17504813124 37441

Pringle, H. (2004). Celebrity Sells. John Wiley and Sons lImited.

PROSES KELAHIRAN BABY KIANO TIGER WONG .. - YouTube. (n.d.). Retrieved February 15, 2021, from https://www.youtube.com/watch?v=201 ci655vPs

Rahmawan, D. (2014). Selebtwits: MicroCelebrity Practitioners in Indonesian Twittersphere. Jurnal Kajian Komunikasi, 2(1), 1. https://doi.org/10.24198/jkk.v2i1.6046

Snickars, P., \& Vonderau, P. (2009). Introduction. In P. Snickars \& P. Vonderau (Eds.), The YouTube Reader (pp. 9-21). National Library of Sweden.

Suha, S. A. (2020). The Case of Family Vloggers. https://www.thedailystar.net/shout/ne ws/the-case-family-vloggers-1864195

Sutriono, S., \& Haryatmoko, H. (2018). Selebriti dan Komodifikasi Kapital di Media Sosial. Journal Acta Diurna, 14(2), 99. https://doi.org/10.20884/1.actadiurna. 2018.14.2.1363 
Yessica, Y. (2017). Pengaruh Seleberiti Endorser Melalui Media Sosial Terhadap Minat Beli Konsumen (Survey Chelsea Olivia Sebagai Selebriti Endorser Pada Siswi Sekolah Kristen Ketapang 1 Kelas 10 dan 11 Tahun Ajaran 2016 - 2017).
Prologia,
1(1),
287-292.

https://doi.org/10.24912/PR.V1I1.1418 